UDC 66.011/66.012:662.765

\title{
GLOBAL FLOWSHEET OF CONTROL ETHYLEN REGION OF A CHEMICAL- TECHNOLOGICAL COMPLEX ON PROCESSING CRACKING AND PYROLYSIS GASES WITH CONSIDERATION FOR NON-STATIONARITY OF THE PROCESSES PROCEEDING IN IT
}

\author{
I.I.Osmanova \\ M.Nagiyev Institute of Catalysis and Inorganic Chemistry, NAS of Azerbaijan
}

agil-s@mail.ru

Received 10.06.2019

\begin{abstract}
The article presents a course and results of conducting the processes of ethylenic region of chemical technological complex according to the proposed earlier [1] flowsheet of their calculations under nonstationary conditions. The tasks of their optimal conduction have been decided and on the basis of work carried out general flowsheet of conducting ethylenic region of studied complex taking into account non-stationarity of the processes proceeding there, was developed.
\end{abstract}

Keywords: non-stationarity, conduction functions, production capacity, dynamics, activity, blockflowsheet, general flowsheet of conduction.

doi

The purpose of work consists in maintaining optimal production capacities of the target products in ethylenic region of chemical technological complex (CTC), found out for stationary conditions of their proceeding at optimization of CTC, not depending on reasons at which this stationarity is destroyed.

\section{Fulfillment of work}

According to a flowsheet of the basic actions, proposed in [1] to achieve the purpose set there are provided the results of their subsequent fulfillment for the concrete processes of ethylenic region. Regime parameters of the processes and denotions to them are presented references corresponding to each process.

por [2]

Dealkylation of toluene with water va-

1. Stoichiometric flowsheet of the process:

$$
\begin{aligned}
& \mathrm{C}_{6} \mathrm{H}_{5} \mathrm{CH}_{3}+2 \mathrm{H}_{2} \mathrm{O} \rightarrow \mathrm{C}_{6} \mathrm{H}_{6}+\mathrm{CO}_{2}+3 \mathrm{H}_{2}, \\
& \mathrm{C}_{6} \mathrm{H}_{5} \mathrm{CH}_{3}+\mathrm{H}_{2} \mathrm{O} \rightarrow \mathrm{C}_{6} \mathrm{H}_{6}+\mathrm{CO}+2 \mathrm{H}_{2}, \\
& \mathrm{C}_{6} \mathrm{H}_{5} \mathrm{CH}_{3}+\mathrm{H}_{2} \rightarrow \mathrm{C}_{6} \mathrm{H}_{6}+\mathrm{CH}_{4}, \\
& 2 \mathrm{C}_{6} \mathrm{H}_{5} \mathrm{CH}_{3} \rightarrow \sum \mathrm{CH}_{3} \mathrm{C}_{6} \mathrm{H}_{4} \mathrm{CH}_{3}+\mathrm{C}_{6} \mathrm{H}_{6} .
\end{aligned}
$$

2. Stationary kinetic model:

$$
\begin{aligned}
& w_{\mathrm{BENZ}}=\left[\frac{k_{\mathrm{EFF}}^{1} P_{\mathrm{TOL}}}{1+K_{\mathrm{TOL}} P_{\mathrm{TOL}}}+\frac{k_{\mathrm{EFF}}^{2} P_{\mathrm{TOL}}}{1+K_{\mathrm{TOL}} P_{\mathrm{TOL}}}+\right. \\
& \left.+\frac{k_{\mathrm{EFF}}^{3} P_{\mathrm{TOL}} P_{\mathrm{H}_{2}}}{1+K_{\mathrm{TOL}} P_{\mathrm{TOL}}+K_{\mathrm{H}_{2}} P_{\mathrm{H}_{2}}}\right] \text {; } \\
& -w_{\mathrm{TOL}}^{\Sigma}=\frac{k_{\mathrm{EFF}}^{1} P_{\mathrm{TOL}}}{1+K_{\mathrm{TOL}} P_{\mathrm{TOL}}}+\frac{k_{\mathrm{EFF}}^{2} P_{\mathrm{TOL}}}{1+K_{\mathrm{TOL}} P_{\mathrm{TOL}}}+ \\
& +\frac{k_{\mathrm{EFF}}^{3} P_{\mathrm{TOL}} P_{\mathrm{H}_{2}}}{1+K_{\mathrm{TOL}} P_{\mathrm{TOL}}+K_{\mathrm{H}_{2}} P_{\mathrm{H}_{2}}}+\frac{k_{\mathrm{EFF}}^{4} P_{\mathrm{TOL}}}{1+K_{\mathrm{TOL}} P_{\mathrm{TOL}}} ; \\
& W_{\mathrm{H}_{2}}=\frac{k_{\mathrm{EFF}}^{1} P_{\mathrm{TOL}}}{1+K_{\mathrm{TOL}} P_{\mathrm{TOL}}}+\frac{k_{\mathrm{EFF}}^{2} P_{\mathrm{TOL}}}{1+K_{\mathrm{TOL}} P_{\mathrm{TOL}}}- \\
& -\frac{k_{\mathrm{EFF}}^{3} P_{\mathrm{TOL}} P_{\mathrm{H}_{2}}}{1+K_{\mathrm{TOL}} P_{\mathrm{TOL}}+K_{\mathrm{H}_{2}} P_{\mathrm{H}_{2}}} \text {; } \\
& w_{\mathrm{XYL}}=\frac{k_{\mathrm{EFF}}^{4} P_{\mathrm{TOL}}}{1+K_{\mathrm{TOL}} P_{\mathrm{TOL}}} ; w_{\mathrm{CO}_{2}}=\frac{k_{\mathrm{EFF}}^{1} P_{\mathrm{TOL}}}{1+K_{\mathrm{TOL}} P_{\mathrm{TOL}}} ; \\
& w_{\mathrm{CO}}=\frac{k_{\mathrm{EFF}}^{2} P_{\mathrm{TOL}}}{1+K_{\mathrm{TOL}} P_{\mathrm{TOL}}} ; w_{\mathrm{CH}_{4}}=\frac{k_{\mathrm{EFF}}^{3} P_{\mathrm{TOL}} P_{\mathrm{H}_{2}}}{1+K_{\mathrm{TOL}} P_{\mathrm{TOL}}+K_{\mathrm{H}_{2}} P_{\mathrm{H}_{2}}}, \\
& k_{\mathrm{EFF}}^{j}=k_{0}^{\mathrm{j}} \cdot \exp \left(-\frac{E_{\mathrm{EFF}}^{\mathrm{j}}}{R T}\right), K_{i}=K_{0}^{i} \exp \left(\frac{Q_{i}}{R T}\right)
\end{aligned}
$$


3. Equation of heat balance:

$$
\frac{\mathrm{d} T}{\mathrm{~d} l}=0 .
$$

4. Function of deactivatisn of a catalyst:

$$
\theta=\mathrm{e}^{-k_{\mathrm{A}} \alpha \tau} \text {. }
$$

5. By introducing function of a catalyst's deactivation (3) into equation of benzene formation velocity

$$
\begin{aligned}
w_{\mathrm{BENZ}} & =\left[\frac{k_{\mathrm{EFF}}^{1} P_{\mathrm{TOL}}}{1+K_{\mathrm{TOL}} P_{\mathrm{TOL}}}+\frac{k_{\mathrm{EFF}}^{2} P_{\mathrm{TOL}}}{1+K_{\mathrm{TOL}} P_{\mathrm{TOL}}}+\right. \\
& \left.+\frac{k_{\mathrm{EFF}}^{3} P_{\mathrm{TOL}} P_{\mathrm{H}_{2}}}{1+K_{\mathrm{TOL}} P_{\mathrm{TOL}}+K_{\mathrm{H}_{2}} P_{\mathrm{H}_{2}}}\right] \cdot \theta,
\end{aligned}
$$

together with other equations of the system (2) constructed dynamic kinetic model.
6. Function of conducting - regression dependences of selectivity of benzene and xylene on additions of hydrogen and time of a catalysts work:

$$
\begin{aligned}
& S_{\mathrm{BENZ}}=73.0071+0.5068 \mathrm{M}+0.003 \tau, \\
& S_{\mathrm{XYL}}=-0.2770-0.1354 \mathrm{M}+0.0082 \tau .
\end{aligned}
$$

The system of equations $(2,3)$ with consideration (4-7) is a complete mathematical model of the process for non-stationary conditions.

Suggested method of hydrogen additive to the reactionary mixture $\left(\mathrm{TOL}+\mathrm{H}_{2} \mathrm{O}\right)$ in found out interval of their change $(0.2-1.5)$ permits preserve production capacity of benzene at needed optima level (76.6\%).

7. Results of calculation:

Table 1. Results of a catalysts work within 1000 hours (without additions of hydrogen)

\begin{tabular}{|l|c|c|c|c|c|}
\hline Time of catalysts work, $\mathrm{h}$ & 200 & 400 & 600 & 800 & 1000 \\
\hline Selectivity for benzene, $\%$ & 76.6 & 75.8 & 75.0 & 74.4 & 73.2 \\
\hline Selectivity for xylenes, \% & 1.2 & 2.3 & 8.4 & 9.9 & 11.2 \\
\hline
\end{tabular}

Table 2. The best yields of benzene at indicated additions of hydrogen to reactionary mixture at inlet into reactor

\begin{tabular}{|c|c|c|c|c|c|}
\hline \multirow{2}{*}{$\begin{array}{c}\text { Volumetric velocity of feeding } \\
\text { TOL }+\mathrm{H}_{2} \mathrm{O}+\mathrm{H}_{2}, \mathrm{~h}^{-1}\end{array}$} & \multicolumn{3}{|c|}{ Ratios } & $\begin{array}{c}\text { Selectivity by } \\
\text { benzene, } \%\end{array}$ & $\begin{array}{c}\text { Selectivity by } \\
\text { xylenes, } \%\end{array}$ \\
\cline { 2 - 5 } & $\mathrm{TOL}$ & $\mathrm{H}_{2} \mathrm{O}$ & $\mathrm{H}_{2}$ & $76.6^{\text {opt }}$ & $7.5^{\text {opt }}$ \\
\hline $1800^{\text {opt }}$ & 1 & 4 & - & 75.6 & 7.5 \\
\hline 1835 & 1 & 4 & 0.1 & 76.0 & 7.4 \\
\hline 1872 & 1 & 4 & 0.2 & 76.2 & 7.1 \\
\hline 2070 & 1 & 4 & 0.5 & 76.5 & 6.9 \\
\hline 2160 & 1 & 4 & 0.75 & 77.0 & 6.6 \\
\hline 2250 & 1 & 4 & 1 & 77.1 & 6.5 \\
\hline 2340 & 1 & 4 & 1.25 & 77.3 & 6.3 \\
\hline 230 & 1 & 4 & 1.50 & 75.5 & 8.4 \\
\hline
\end{tabular}

Alkylation of benzene by ethylene [3]

1. Stoichiometric flowsheet of process:

$$
\begin{aligned}
& \mathrm{B}+\mathrm{E} \stackrel{k_{1}}{\longrightarrow} \mathrm{EB}, \\
& \mathrm{EB}+\mathrm{E} \stackrel{k_{2}}{\longrightarrow} \mathrm{PAB}, \\
& \mathrm{PAB}+\mathrm{B} \stackrel{k_{3}}{\longrightarrow} 2 \mathrm{~EB}, \\
& 2 \mathrm{~EB}+\mathrm{B} \stackrel{k_{4}}{\longrightarrow} \mathrm{PAB} .
\end{aligned}
$$

2. Stationary kinetic model:

$$
\begin{aligned}
& \frac{\mathrm{d} X_{\mathrm{EB}}}{\mathrm{d} l}=\left[\frac{(\gamma P-\mathrm{A})\left(K_{1} C_{\mathrm{c}} X_{\mathrm{B}}-K_{2} C_{\mathrm{c}} X_{\mathrm{EB}}\right)}{w_{l}(1+\mathrm{B})}+\frac{K_{3} C_{\mathrm{c}} C_{\mathrm{B}} X_{\mathrm{PAB}}-K_{4} C_{\mathrm{c}} C_{\mathrm{B}} X_{\mathrm{EB}}^{2}}{w_{l}}\right] \\
& \frac{\mathrm{d} X_{\mathrm{PAB}}}{\mathrm{d} l}=\frac{K_{\mathrm{D}} G_{\mathrm{g}}^{2} \mathrm{~T}(\gamma \mathrm{P}-\mathrm{A}) K_{2} C_{\mathrm{c}} X_{\mathrm{EB}}}{273 \mathrm{M}_{\mathrm{g}} \gamma_{\mathrm{g}} \mathrm{FP} w_{l}}+\frac{K_{4} C_{\mathrm{c}} X_{\mathrm{B}} X_{\mathrm{EB}}^{2}-K_{3} C_{\mathrm{c}} C_{\mathrm{B}} X_{\mathrm{PAB}}}{w_{l}},
\end{aligned}
$$


where

$$
\begin{aligned}
& \mathrm{A}=\frac{\left(\mathrm{K}_{3} \mathrm{X}_{\mathrm{B}} \mathrm{X}_{\mathrm{PAB}}-\mathrm{K}_{4} \mathrm{X}_{\mathrm{EB}}^{2}\right) \mathrm{C}_{\mathrm{k}} \mathrm{n}_{\mathrm{B}}^{2} \gamma_{1}}{\mathrm{~K}_{\mathrm{D}} \mathrm{W}_{\mathrm{g}}}, \\
& \mathrm{B}=\frac{\left(\mathrm{K}_{1} \mathrm{X}_{\mathrm{B}}+\mathrm{K}_{2} \mathrm{X}_{\mathrm{EB}}\right) \mathrm{C}_{\mathrm{k}} \mathrm{n}_{\mathrm{B}}}{\mathrm{K}_{\mathrm{D}} \mathrm{W}_{\mathrm{g}}}
\end{aligned}
$$

3. $\frac{\mathrm{d} T}{\mathrm{~d} l}=0$ (isotermic reactor).

4. Conducting function $\theta=\mathrm{G}_{\mathrm{ET}} / \mathrm{G}_{\mathrm{B}}$ :

$$
\bar{\theta}=0.3 e^{-0.2 \tau} \text { (design value) }
$$

5. By introducing $\theta$ into equation (9)

$$
\begin{aligned}
\frac{d X_{E B}}{d l} & =\left[\frac{(\gamma P-A)\left(K_{1} C_{k} X_{B}-K_{2} C_{k} X_{E B}\right)}{W_{1}(1+B)}+\right. \\
& \left.+\frac{\mathrm{K}_{3} C_{k} C_{b} X_{P A B}-K_{4} C_{k} C_{B} X_{b}^{2}}{W_{1}}\right] \cdot \theta
\end{aligned}
$$

dynamic kinetic model of the process jointly with equation (10) was received. The system of equations (10), (11), (13) taking an account for (12) is a complete mathematical one of the process with consideration for non-stationarity of its proceeding.

6. Block-flowsheet of optimal conducting of the process in non-stationary conditions:

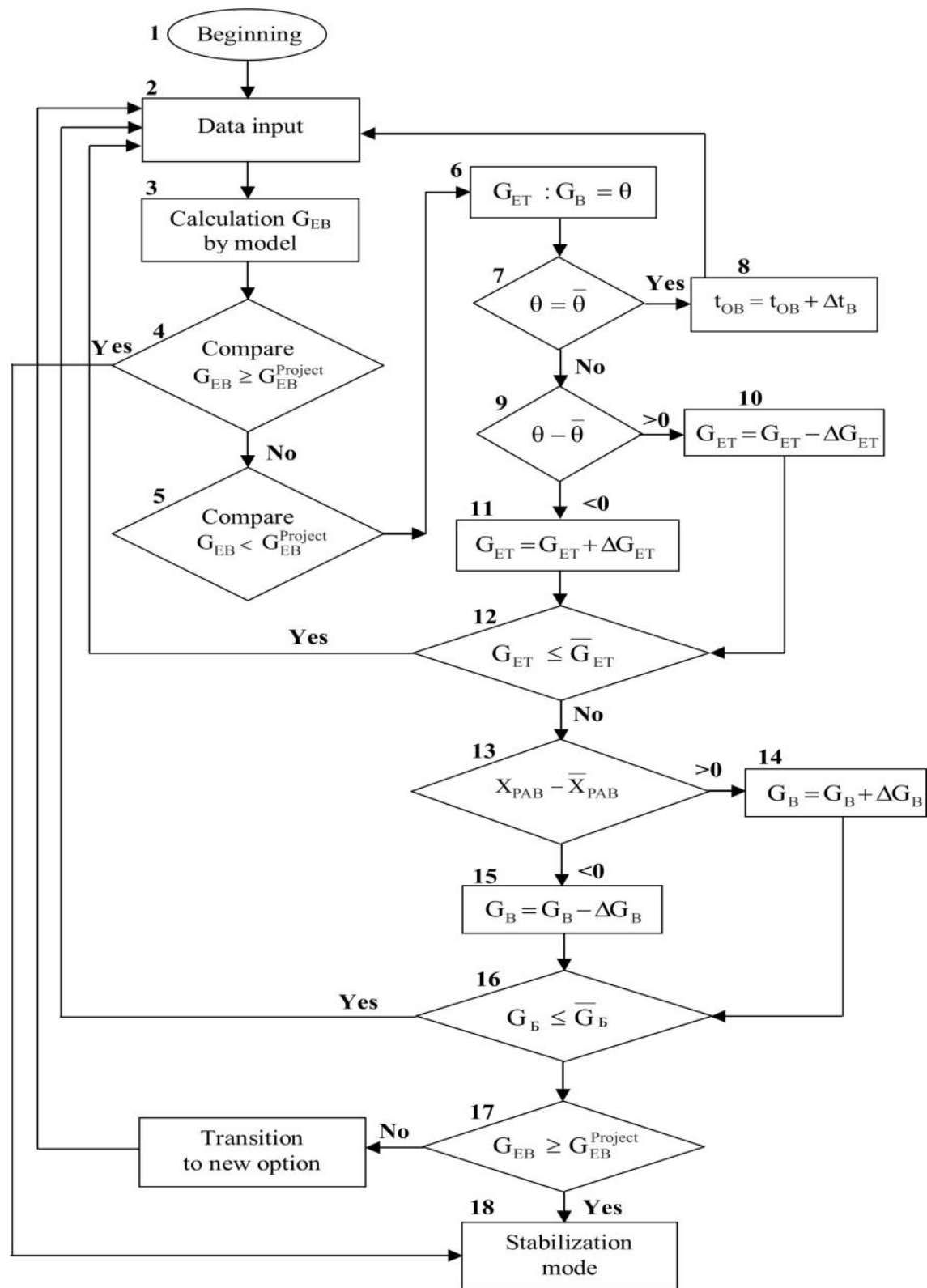


7. Results of calculation:

Table 3. Comparison of well-known and proposed methods of proceeding process

\begin{tabular}{|c|c|c|c|c|c|c|c|c|c|c|}
\hline \multirow{2}{*}{$№$} & \multicolumn{9}{|c|}{ Industrial method } & \multicolumn{6}{c|}{ Proposed method } \\
\cline { 2 - 12 } & \multicolumn{3}{|c|}{ Inlet into alkylator, kg/h } & \multicolumn{2}{c|}{ Yield, kg/h } & \multicolumn{3}{c|}{ Inlet into alkylator, kg/h } & \multicolumn{3}{c|}{ Yield, kg/h } \\
\cline { 2 - 12 } & $G_{c c}^{f}$ & $G_{\mathrm{ET}}$ & $G_{\mathrm{B}}$ & $G_{\mathrm{PAB}}$ & $G_{\mathrm{EB}}$ & $G_{c c}^{f}$ & $G_{\mathrm{ET}}$ & $G_{\mathrm{B}}$ & $G_{\mathrm{PAB}}$ & $G_{\mathrm{EB}}$ \\
\hline 1 & 420 & 5348.12 & 51477.17 & 4517.20 & 20976.56 & 420 & 5183.20 & 51134.52 & 4416 & 21071.91 \\
\hline 2 & 420 & 5253.88 & 51178.45 & 4452.80 & 20803.20 & 420 & 5183.20 & 51134.52 & 4416 & 21106.58 \\
\hline 3 & 420 & 5654.40 & 54473.20 & 4554.00 & 21063.24 & 420 & 5183.20 & 51134.52 & 4416 & 21063.24 \\
\hline 4 & 420 & 4829.80 & 46477.94 & 4517.20 & 20629.84 & 420 & 5183.20 & 51134.52 & 4416 & 21071.91 \\
\hline 5 & 420 & 5583.72 & 53858.18 & 4259.60 & 21037.24 & 420 & 5183.20 & 51134.52 & 4416 & 21149.92 \\
\hline 6 & 420 & 5501.26 & 53067.44 & 4121.60 & 20993.90 & 420 & 5183.20 & 51134.52 & 4416 & 21167.26 \\
\hline 7 & 420 & 5030.06 & 46978.74 & 4664.40 & 20673.18 & 420 & 4924.04 & 48577.79 & 4195.2 & 20954.89 \\
\hline 8 & 420 & 5124.30 & 48481.15 & 4728.80 & 20716.52 & 420 & 3592.90 & 35495.44 & 3054.4 & 20868.21 \\
\hline 9 & 420 & 5242.10 & 50677.65 & 4084.80 & 20794.53 & 420 & 3592.90 & 35495.44 & 3054.4 & 20846.54 \\
\hline
\end{tabular}

By ratio of the concentrations of not reacted ethylene and benzene corrected are their amounts at inlet of alkylator to obtain at outlet from it demanded by project amount of ethyl benzene got for stationary conditions. Application of the proposed method of conducting makes it possible to increase by $1 \%$ of ethylbenzene yields and decrease by $8-10 \%$ amounts of polyalkylbenzenes.

\section{rene [4].}

\section{Dehydration of ethylbenzene to sty-}

1. Stoichiometric flowsheet of the process:

$\mathrm{C}_{8} \mathrm{H}_{10} \leftrightarrow \mathrm{C}_{8} \mathrm{H}_{8}+\mathrm{H}_{2}$

$\mathrm{C}_{8} \mathrm{H}_{10}+\mathrm{H}_{2} \leftrightarrow \mathrm{C}_{7} \mathrm{H}_{8}+\mathrm{CH}_{4}$

$\mathrm{C}_{8} \mathrm{H}_{10}+\mathrm{H}_{2} \leftrightarrow \mathrm{C}_{6} \mathrm{H}_{6}+\mathrm{C}_{2} \mathrm{H}_{6}$

2. Stationary kinetic model:

$\frac{\mathrm{dx}_{2}}{\mathrm{~d} l}=\lambda_{2} \frac{1-\mathrm{x}_{2}-\mathrm{x}_{5}}{1+\mathrm{x}_{2}} ;$

$\frac{\mathrm{dx}_{5}}{\mathrm{~d} l}=\lambda_{5} \frac{1-\mathrm{x}_{2}-\mathrm{x}_{5}}{\left(1+\mathrm{x}_{2}\right)^{2}}\left(\mathrm{x}_{2}-\mathrm{x}_{5}\right)$,

$x_{5}=x_{3}+x_{4} ; \lambda_{2}=\mathrm{k}_{2} \beta / \mathrm{W}_{0}$,

$\lambda_{5}=\mathrm{k}_{5} \beta \mathrm{C}_{0} / \mathrm{W}_{0} ; \beta=\frac{\mathrm{F}}{\mathrm{F}_{0}}$.

3. Equation of heat balance:

$$
\frac{\mathrm{d} T}{\mathrm{~d} l}=\frac{N_{0}}{C_{p \text { mid }} \cdot N_{T}} \mathrm{Q}_{2} \frac{\mathrm{d} x_{2}}{\mathrm{~d} l},
$$

$$
\begin{gathered}
C_{p \text { mid }}=C_{p \mathrm{H}_{2} \mathrm{O}} \frac{\mathrm{M}}{\mathrm{M}+\left(1+x_{2}\right)}+\frac{1}{\mathrm{M}+\left(1+x_{2}\right)} \times \\
\times\left[x_{2}\left(C_{p \text { cт. }}+C_{p \mathrm{H}_{2}}-C_{p \text { eb. }}\right)+C_{p \text { eb. }}\right] .
\end{gathered}
$$

4. Deactivation functions:

$\theta=1-\left[(1-n) \mathrm{Ae}^{-\frac{E_{\mathrm{A}}}{R T}}\left(\mathrm{~N}_{0} \mathrm{M}\right)\left(\tau-\tau_{0}\right)\right]^{\frac{1}{1-n}}$

5. By introducing $\theta$ into the right part of equation (15):

$$
\frac{\mathrm{d} x_{2}}{\mathrm{~d} l}=\lambda_{2} \frac{1-x_{2}-x_{5}}{1+x_{2}} \times \theta
$$

dynamic kinetic model with equation (16) of the process was received.

6. Function of conducting - regression equations of dependences of ethylbenzene conversion to styrene $X_{2}$ and selectivity of the process $S$ on degree of dilution of feed stock by water vapor $\mathrm{M}$, temperature of vapor feed stock mixture at inlet to reactor $t_{0}$ and time of work of work setting $\tau$

$$
\begin{gathered}
x_{2}=1.257042166+0.002389131 \cdot \mathrm{M}- \\
-0.001472064 \cdot t_{0}-0.00000426802 \cdot \tau \\
S=0.791438979+0.003849415 \cdot \mathrm{M}- \\
0.000108156 \cdot t_{0}-0.00000528188 \cdot \tau
\end{gathered}
$$

The system of equations (16), (17), (19) with consideration for (18-21) is an entire mathematical model of the process for non-stationary conditions. 
7. Results of calculation:

Table 4. The optimal version of conducting the process

\begin{tabular}{|c|c|c|c|c|c|c|c|c|c|c|c|c|}
\hline \multirow{2}{*}{\begin{tabular}{|c|} 
Conver- \\
sion of \\
ethyl \\
benzene \\
to styrene, \\
$\mathrm{X}_{2}$; selec- \\
tivity $\mathrm{S}$, \\
mol \%
\end{tabular}} & \multirow{2}{*}{ 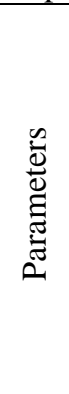 } & \multicolumn{10}{|c|}{ Time of a catalyst's work, hours } & \multirow{2}{*}{$\begin{array}{c}\text { An average } \\
\text { value of water } \\
\text { vapor consump- } \\
\text { tion for } 5000 \\
\text { hours of a cata- } \\
\text { lysts work }\end{array}$} \\
\hline & & 500 & 1000 & 1500 & 2000 & 2500 & 3000 & 3500 & 4000 & 45000 & 5000 & \\
\hline \multirow{3}{*}{$\begin{array}{c}X_{2}=41 \\
S=92\end{array}$} & $\mathrm{M}$ & 16.7 & 16.9 & 17.1 & 17.4 & 17.7 & 18.2 & 18.7 & 19.4 & 20.2 & 21.3 & \multirow{3}{*}{$\begin{array}{c}\bar{G}_{\text {w.v. }}=68879.16 \\
\mathrm{kq} / \mathrm{h}\end{array}$} \\
\hline & $t_{0}$ & 597.6 & 597.3 & 597.1 & 596.4 & 595.7 & 594.9 & 594.1 & 593.3 & 592.6 & 592.1 & \\
\hline & $N_{\text {w.v. }}$ & 3483.62 & 3525.34 & 3567.06 & 3629.64 & 3692.22 & 3763.76 & 3900.82 & 4046.84 & 4213.72 & 4443.18 & \\
\hline
\end{tabular}

Table 5. Results of a catalyst's work after 5000 hours

\begin{tabular}{|c|c|c|c|c|}
\hline $\begin{array}{c}\text { Time of a catalyst's } \\
\text { work, } \\
\tau, \mathrm{h}\end{array}$ & $\begin{array}{c}\text { Temperature of vapor } \\
\text { feedstock mixture at } \\
\text { inlet to a reactor, } t_{\mathrm{o}},{ }^{0} \mathrm{C}\end{array}$ & $\begin{array}{c}\text { Degree of dilution of } \\
\text { feedstock by water } \\
\text { vapor, M, mol/mol }\end{array}$ & $\begin{array}{c}\text { Conversion of } \\
\text { ethylbenzene to sty- } \\
\text { rene } X_{2}, \%, \text { mol }\end{array}$ & $\begin{array}{c}\text { Selectivity of } \\
\text { the process, } \mathrm{S} \\
\%, \mathrm{~mol}\end{array}$ \\
\hline 5000 & 592.1 & 21.3 & 41.0 & 92 \\
\hline 5500 & 593.0 & 21.3 & 41.2 & 91.9 \\
\hline 6000 & 594.0 & 21.3 & 41.3 & 91.85 \\
\hline 6500 & 595.0 & 21.3 & 41.35 & 91.70 \\
\hline 7000 & 596.0 & 21.3 & 41.3 & 91.60 \\
\hline 7500 & 597.0 & 21.3 & 41.28 & 91.40 \\
\hline
\end{tabular}

As we see, to keep up constant for whole period of work the optimal values of styrene yield at $41 \%$ and selectivity of the process at $92 \%$, it is expedient to decrease mixture temperature at inlet to reactor from 597.6 at the beginning to $592.1^{\circ} \mathrm{C}$ in the end of a catalyst's work and degree of delution of feedstock by water vapor to increase simultaneously from 16.7 to 21.3 .

It is radically differed from industrial way of carrying out the process, where to maintain activity of a catalyst they resort to increasing temperature of vapor feedstock mixture at inlet to a reactor, at the same time not changing delution degree of feedstock by water vapor that leads to sooner blocking of catalyst's surface by toxicants.

It is seen in the table that a rise temperature about by $4^{0} \mathrm{C}$ for subsequent 2000 hours permits to increase a little yield, keeping up it within a frame of optimal, and though selectivity of the process with increase in temperature will decrease a little, however till 7000 hours the results of a catalyst's work may be considered satisfactory.

The proposed way of optimal conducting process will enable not decreasing styrene yield

not only to reduce expenditures for the process because of lesser consumption of water vapor in comparison with industrial by $25 \%$, but also to prolong service term for 2000 hours work of a catalyst (7000 hours against 5000 hours at the plant). Result-is a tangible economic advantage.

\section{Polymerization of styrene [5]}

1. Stoichiometric flowsheet of the process:<smiles>CC=CCCCc1ccccc1</smiles>

2. Stationary kinetic model:

$$
\begin{aligned}
& \frac{\mathrm{d} x_{\mathrm{m}}}{\mathrm{d} t}=\left[k_{\mathrm{EFF}}\left(1-x_{\mathrm{m}}\right) \sqrt{\frac{I_{0}\left(1-x_{\mathrm{I}}\right)}{\left(1+\varepsilon x_{\mathrm{m}}\right) F\left(x_{\mathrm{m}}\right)}}\right] ; \\
& \mathrm{d} x_{\mathrm{I}} / \mathrm{d} t=k_{\mathrm{d}}\left(1-x_{\mathrm{I}}\right), \\
& x_{\mathrm{I}}=\frac{\left(I_{0}-I\right)}{I_{0}} ; \quad I_{0}=\frac{\mathrm{M}_{\text {inic }}}{\mathrm{M}_{0 \text { inic }} \mathrm{V}_{\mathrm{st}}^{0}} ; \quad k_{\mathrm{EFF}}=k_{\mathrm{p}} \sqrt{\frac{2 k_{\mathrm{d}} \mathrm{f}}{k_{\mathrm{to}}}} ; \\
& k_{\mathrm{t}}=k_{\mathrm{to}} F\left(x_{\mathrm{m}}\right) ; \varepsilon=\frac{\rho_{\mathrm{st}}}{\rho_{\mathrm{ps}}}-1 ;
\end{aligned}
$$


3. Equation of heat balance:

$\rho \mathrm{VC}_{\mathrm{p}} \frac{\mathrm{dT}}{\mathrm{dt}}=\mathrm{M}_{\mathrm{st}} \Delta \mathrm{H} \frac{\mathrm{dx} \mathrm{m}_{\mathrm{m}}}{\mathrm{dt}}-\mathrm{q}_{\mathrm{pot}}$

4. Function of non-stationarity:

$$
\theta=\mathrm{e}^{-\mathrm{k} \alpha \mathrm{N}_{\mathrm{st}} \mathrm{t}}
$$
equation (23) $\frac{\mathrm{d} x_{\mathrm{m}}}{\mathrm{d} t}=\left[k_{\mathrm{EFF}}\left(1-x_{\mathrm{m}}\right) \sqrt{\frac{\mathrm{I}_{0}\left(1-x_{\mathrm{I}}\right)}{\left(1+\varepsilon x_{\mathrm{m}}\right) F\left(x_{\mathrm{m}}\right)}}\right] \cdot \theta$,

jointly with (24) and (25) dynamic kinetic model of the process is received.

System of equations (24), (25), (27), with consideration of (26) is a complete mathematical model of the process for non-stationary conditions.

6. Block-flowsheet of optimal conduction of the process in non-stationary conditions:

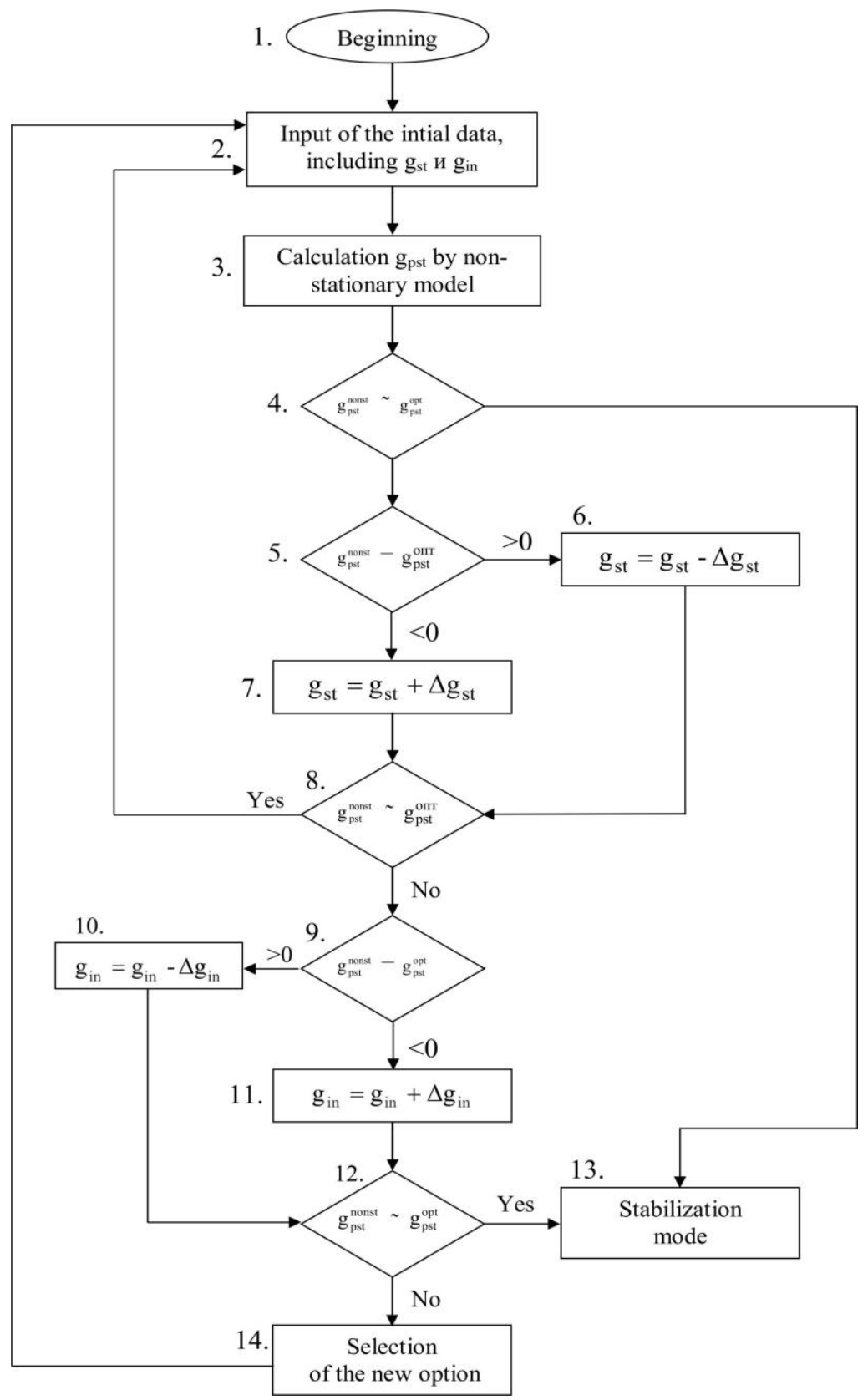


7. Results of calculation:

At difference of polystyrene productivity from its stationary value, changing a value of $\theta$ on the account of increasing purity of the styrene feeded into a reactor or amount of initiator, we'll be able to regulate the process and obtain the required yield of a target product.

\section{Conclusion}

The developed algorithms of a choice for optimal conducting the processes of ethylene region with own non-stationarity function found out for each of them permit to calculate operatively the regimes of work in non-stationary industrial conditions for the purpose to receive demanded values of productivities of the target products obtained already at optimization of CTC, but in stationary conditions.

As the processes of ethylene region do not work synchronously and periods of changing catalyst's activity do not coincide in time, in addition the reasons of destroying stationarity in each process are different, it is impossible to make up a general function of control for a whole region. However the mathematical models of the processes developed with consideration for non-stationary activity of catalyst's possess a flexible structure, i.e. in the course of time the process of self-adjustment of these models takes place. Adjusting mathematical models is carried out both periodically through certain intervals of time or disagreement between calculated and experimental values exceeds the definite values given beforehand. At similar approach the region becomes a flexible chemical-technological system maintaining own work capacity even at possible outward and inner effects.

A general flowsheet of control for ethylene region in CTC is shown in a Figure, where every process proceeding under non-stationary conditions corresponds to control block of its own, using non-stationarity function, concrete for this process.

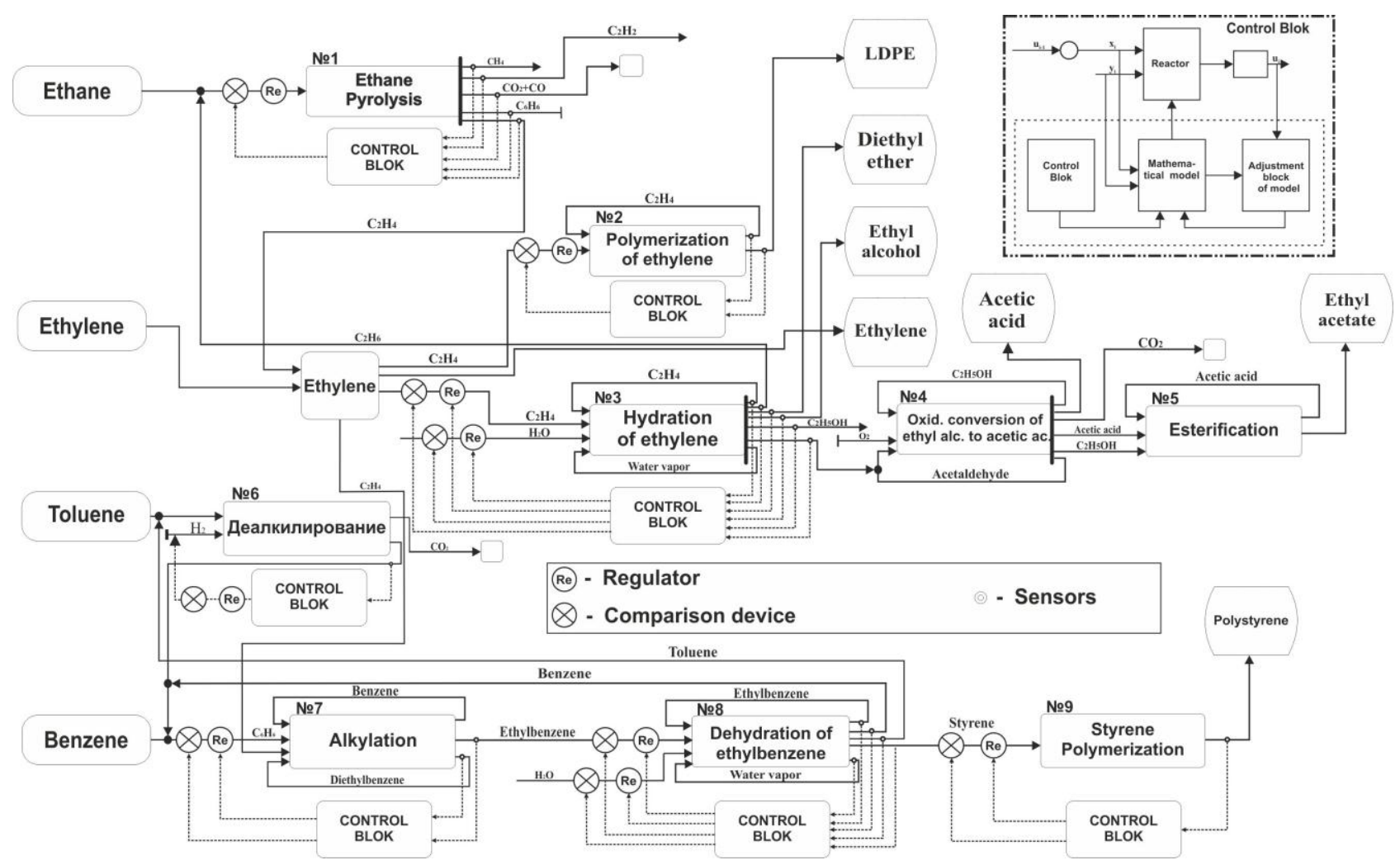

General flowsheet for control of the ethylene region of CTC. 


\section{References}

1. Osmanova I.I. Solution of the problems of nonstationarity of the processes of ethylene region of the chemical-technological complex on processing cracking and pyrolysis gases. Azerb. chem. journ. 2019. No 3. P. 75-83.

2. Aliyev A.M., Osmanova I.I., Balayev I.V., Huseynova A.M., Safarov A.R. The method of control for the process of dealkylating toluene by water vapor. Scienc. News. Sumgait University. 2018. No 3. P. 42-48.

3. Aliyev A.M., Osmanova I.I., Safarov A.R., Huseynova A.M., Aliyeva X.A. Blok-skhema optimalnogo upravleniia protcessom alkilirovaniia benzola etilenom v nestatcionarnykh usloviiakh. Abstracts of Scien. conf. "Nagiye Readings" dedicated to the $110^{\text {th }}$ anniversary of academician M.Nagiev. Baku. 2018. P. 133.

4. Aliyev A.M., Osmanova I.I., Safarov A.R., Huseynova A.M., Aliyeva Kh.A. Control of the process of ethylbenzene dehydration to styrene under non-stationary conditions. Azerb. chem. journ. 2018. No 1. P. 17-22.

5. Aliyev A.M., Osmanova I.I., Safarov A.R., Huseynova A.M., Balayev I.V. Control of the process of styrene polymerization in non-stationary conditions. Azerb. chem. journ. 2018. No 3. P. 33-37.

\section{Additional remarks for references}

1. $C_{p}$ mid - middle heat capacity of components, $\mathrm{kcal} / \mathrm{kmol}^{-1} \cdot \mathrm{deg}^{-1}$;

2. $C_{p \text { st }}, C_{p}$ EB - heat capacities of styrene and ethylbenzene, $\mathrm{kcal} / \mathrm{kmol} \cdot \mathrm{deg}$.;

3. $K_{\mathrm{D}}$ - constant of diffusion exchange;

4. $K_{\text {eff }}^{j}$ - effective constant of $j$-th reaction velocity;

5. $N_{\mathrm{o}}$ - feeding velocity of ethylbenzene, $\mathrm{kmol} / \mathrm{h}$;

6. $N_{\text {w.v. }}-$ amount of water vapor, $\mathrm{kmol} / \mathrm{h}$;

7. $n_{\mathrm{B}}-$ mole velocity of benzene, $\mathrm{mol} / \mathrm{s}$;

8. $P_{\mathrm{TOL}}$ - partial pressure of toluene;

9. $w_{\mathrm{g}}, w_{1}$ - linear velocities of gas and liquid flows, $\mathrm{mol} \mathrm{m}^{-3} \cdot \mathrm{s}^{-1}$;
10. $w_{\mathrm{BENZ}}, w_{\mathrm{XYL}}-$ benzene and xylene formation velocity, $\mathrm{mol} \mathrm{m}^{-2} \mathrm{~h}^{-1}$;

11. $w_{\mathrm{TOL}}^{\Sigma}-$ toluene summary conversion velocity, $\mathrm{mol} /\left(\mathrm{m}^{2} . \mathrm{h}\right)$;

12. $X_{\mathrm{B}}, X_{\mathrm{PAB}}, X_{\mathrm{B}}$ - partial moles of benzene, polyalkylbenzene and ethylbenzene;

13. $\gamma_{1}-$ special weight of liquid phase, $\mathrm{kg} / \mathrm{m}^{3}$

14. $G_{c c}^{f}$ - expenditure of fresh catalyst's complex, $\mathrm{kg} / \mathrm{h}$;

15. $N_{T}$ - current amount of ethylbenzene, $\mathrm{kmol} / \mathrm{h}$.

\section{KREKINQ Və PİROLIZZ QAZLARININ EMALININ KIMYəVI TEXNOLOJİ KOMPLEKSINIIN ETILEN REQIONU PROSESLORININ QEYRI-STASIONARLIĞINI NOZORӘ ALMAQLA ÜMUMI IDARӘ SXEMI}

\section{İ.İ.Osmanova}

Məqalədə KTK-in etilen regionu proseslərinin qeyri-stasionar şəraitdə əvvəl təklif edilmiş [1] sxemi üzrə hesablanmış idarə olunmasının gedişi və nəticələri təqdim olunub. Proseslərin qeyri-stasionar şəraitdə optimal idarə olunması məsələsi həll olunub və aparılıan iş nəticəsində KTK-in etilen regionunun qeyri-stasionar şəraitdə baş verməsini nəzərə almaqla ümumi idarə sxemi işlənib hazırlanıb.

Açar sözlar: qeyri-stasionar, idarə olunma funksiyası, məhsuldarlıq, dinamika, aktivlik, blok-sxem, ümumi idarə sxemi.

\section{ОБЩАЯ СХЕМА УПРАВЛЕНИЯ ЭТИЛЕНОВЫМ РЕГИОНОМ ХИМИКО-ТЕХНОЛОГИЧЕСКОГО КОМПЛЕКСА ПО ПЕРЕРАБОТКЕ ГАЗОВ КРЕКИНГА И ПИРОЛИЗА С УЧЕТОМ НЕСТАЦИОНАРНОСТИ ПРОТЕКАЮЩИХ В НЕМ ПРОЦЕССОВ}

\section{И.И.Османова}

В статье представлены ход и результаты управления процессами этиленового региона ХТК по предложенной ранее [1] схеме их расчетов в нестационарных условиях. Решены задачи их оптимального управления и на основании проделанной работы разработана общая схема управления этиленовым регионом ХТК с учетом нестационарности протекающих в них процессов.

Ключевые слова: нестационарность, функиии управления, производительность, динамика, активность, блоксхема, общая схема управления. 